\title{
Pedagogy and Process in 'Organisational Problem-Solving'
}

\author{
J.P.Kawalek \\ Sheffield University, Sheffield, UK
}

J.Kawalek@Sheffield.ac.uk

\begin{abstract}
This paper outlines a case study in which a management development learning process was tightly coupled to organisational change and development objectives. The case discusses how a research and consulting team came together to develop highly reflexive pedagogy to support the work of internal managers who were organised into teams ('learning sets' of sorts, but which came to be known as 'ThinkTanks'). These were to undertake 'organisational problem solving', which involved the integration of various inquiring activities. These learning sets had as their objective, to help members become catalysts of organisational change and performance improvement within a large organisation, applying the inquiring principles.

In order to structure the discourse amongst learning set members, a range of principles and constructs were used. Central to these was a form of process modelling, (termed 'models of teleological human process'). These were carefully introduced to learning set members, and were used to provide a 'basis for a discourse' amongst set members about problematic organisational processes and how to change them. These were based on system theory, in a particular form, in which models were used as a component of inquiry into current and future processes, rather than to 'specify' a given process, in an absolute sense.

The inquiring activities were facilitated by 'Set Advisers', whose role it was to keep the set focused on learning outcomes, and to encourage critical reflexivity in the process. Thus members were encouraged to 'think about the way they were thinking about action', which gave a much more dynamic intellectual basis for the learning set's activities. It also enabled a rich analytical discourse, in which members were expected to justify their perceptions rather than make assertions, or 'defend assertions'. The researchers were genuinely surprised by the way the set members were able to undertake this, and indeed, on reflection, how set members felt 'liberated' by the approach taken.

This had been somewhat an emergent outcome of the main area of research interest, which was focused on problem-solving pedagogy in e-learning contexts. Indeed, the learning sets were op-

Material published as part of this publication, either on-line or in print, is copyrighted by the Informing Science Institute. Permission to make digital or paper copy of part or all of these works for personal or classroom use is granted without fee provided that the copies are not made or distributed for profit or commercial advantage AND that copies 1) bear this notice in full and 2) give the full citation on the first page. It is permissible to abstract these works so long as credit is given. To copy in all other cases or to republish or to post on a server or to redistribute to lists requires specific permission and payment of a fee. Contact Publisher@InformingScience.org to request redistribution permission. erationalised in a 2-day workshop followed by a three month period which was supported by an e-learning technology infrastructure. During the on-line component, the learning set advisers were facilitating each set on-line. This problem based pedagogy proved to give the learning sets a very clear purpose, and this was considered to be a key finding in the research: whilst there have been many attempts at developing on-
\end{abstract}


line communities for learning outcomes, it was the problem-based process that enabled groups to function on-line, because it gave them a certain clarity of goal and purpose.

The pedagogy, methods and learning outcomes of the case, are outlined in this paper.

Keywords: Pedagogy, Teleology, Processes, Organisational Change, ERP, e-learning. 